\title{
Implied Condition of Survivorship in Gifts of Future Interests in California
}

\author{
W.W. Ferrier, Jr.*
}

THE FREQUENT FAIIURE of beneficiaries in wills to live for the expected length of time has given rise to certain legal problems. A younger person does not always outlive an older one. The weak and sickly individual may outlast the one who is healthy and strong. In an automotive, aeronautic and atomic era there is no reason to anticipate a decrease in the instances of this inverse order of mortality. It is not an uncommon occurrence for a beneficiary in a will, contrary to expectations, to die before the testator. In such a case, the gift is said to fail or lapse, unless the testator has anticipated this possibility and has provided in his will for a substitute beneficiary. ${ }^{1}$ Statutory provision for substitute beneficiaries under certain circumstances is well-migh universal. ${ }^{2}$ Even though there is no provision for a substitute beneficiary either in the original will or by any applicable anti-lapse statute, the testator himself sometimes makes such a provision in a later will or codicil executed after his learning of the death of the original beneficiary. Where the gift involves a future interest, however, a different problem arises, namely whether the beneficiary must survive until the time when the future interest becomes possessory. Unlike the case where the beneficiary predeceases the testator, making a later will or codicil after knowledge of the beneficiary's death is very obviously no solution here. The beneficiary has survived the testator but, contrary to the testator's assumptions, has not survived to the time when he was to receive his interest. Here again, the testator should have anticipated the possibility of the beneficiary's earlier death and made express provision in his will as to how the property should go in such a contingency. The fact remains, however, that the instances of neglect to make such provision are of frequent occurrence. These instances, unfortunately, are not restricted to "home-made" wills, drawn without legal advice. No statutory solution, comparable to that effected by the anti-lapse statutes when the beneficiary predeceases the testator, is available. In each case the court must decide whether the testator "intended" to impose survival by the beneficiary to the time of possession as a condition of his gift.

The common law rule of construction in favor of early vesting prevails

* Professor of $\mathrm{Law}$, University of California, Berkeley.

1 See Estate of Brunet, 34 Cal.2d 105, 207 P.2d 567 (1949), in which there was a devise "to Otto Speckter or his Estate." Speckter died after the making of the will and prior to the testator. As he was not related to the testator, the anti-lapse statute (CAL. ProB. CODE § 92) was imapplicable. The court held that the phrase "or his estate" amounted to an alternative devise to the heirs or devisees of the named devisee in the event that he died in the lifetime of the testator. Estate of Glass, $164 \mathrm{Cal}$. 765, 130 Pac. 868 (1913), was distinguished or overruled.

2 Bordwell, The Statutory Law of Wills, 14 Iowa L. Rev. 428 (1929); CaL. Prob. Code § 92. 
in California ${ }^{3}$ and is given recognition in Section 28 of the Probate Code. ${ }^{4}$ What evidence short of an express requirement of survival by the beneficiary is required to rebut this presumption in favor of vesting? Three situations of particular iniportance that have given rise to the problem in Califorma are those (1) where there are no words of present gift of the future interest, (2) where a trust is imvolved, and (3) where there is a gift over in the event of the failure of the beneficiary to survive under some but not all possible contingencies.

\section{Absence of Words Of Present Gift}

A leading California case involving all three of these situations is Estate of Blake.5 The testator left the residue of his estate to trustees to pay over the income in equal portions to two daughters and a granddaughter (the child of a deceased daughter) until each arrived at the age of thirty. The will further provided that "as each my said daughters and granddaughter arrives at the age of thirty years she shall have the right to demand and receive one-third of the rest and residue of my said estate as her distributive share thereof." This was followed by a gift over to the survivor or survivors in the event that either of the daughters or the granddaughter should die without issue "before she receives her distributive share." The two daughters and the granddaughter all survived the testator but the granddaughter died at the age of twenty-seven, leaving a husband and two minor children. The court held that the gift to the granddaughter of one-third of the corpus of the trust property was contingent upon her attaining the age of thirty. It also held, however, that intestacy as to this one-third was prevented by reason of a gift by implication in favor of the granddaughter's two minor children. Such a gift in favor of her issue was implied from the express gift over in the event of the granddaughter's death without issue. ${ }^{6}$

The reason for the court's conclusion that the gift was contingent on survivorship to the specified age was apparently twofold. First, there were no words of present gift. The only basis for any gift of the corpus of the trust property was the conferring on the beneficiary of the right "to demand

\footnotetext{
${ }^{3}$ Among the many cases, see Williams v. Williams, 73 Cal. 99, 14 Pac. 394 (1887), and Estate of Rider, 199 Cal. 742, 251 Pac. 805 (1926).

4 "Testamentary dispositions, including devises and bequests to a person on attaining majority, are presumed to vest at the testator's death." CaL. Prob. Code $\$ 28$, formerly CaI. Crv. CODE $\S 1341$.

It is not clear whether the word "vest" is here used with its primary meaning or whether it is to be interpreted as including interests which could not ever be vested, in the primary sense, at the testator's death but neverthcless, in a secondary sense, could vest at that time, i.e., have the quality of being transmissible. (See Gray, The RuLE Agarnst Perpeturtirs $\$ 118$ (4th ed. 1942), for reference to this secondary meaning of "vested.")

A common law rule of construction akin to that in favor of early vesting is the one in favor of early indefeasibility. (See Restatenrent, Property $§ 243$, comment $i$ (1940), and 2 Powerr, The LAW OF REAL PROPERTy 686 (1950), as to the constructional preference for early indefeasibility.) This rule would not seem to be covered specifically by the wording of. CAL. Prov. Code $\$ 28$. Certain aspects of the rule, however, are embraced in CaL. Pron. Code $\$ 143$ and CAI. Crv. CoDE $\$ 1442$, providing for the strict construction of conditions subsequent. There seems no reason to bchive that this general constructional preference for early indefeasibility is not also a part of California law.

5 I57 Cal. 448, 108 Pac. 287 (1910).

6 On such gifts by imphication, see Restatensent, Property $\$ 242$ (1940), and Note, 37 CATIF. L. REv. 701 (1949).
} 
and receive" the property on attaining the age of thirty. Since that right was future and contingent, the court reasoned, so was any gift to be implied from it. Second, the effect of the gift over in the event of death of the beneficiary without issue, was, in California at least, indicative of an intention not to make a vested gift. While recognizing the presumption or rule of construction in favor of vesting and also the rule that a gift of the income in the interim until the time when the corpus is to be received is indicative that no requirement of survivorship exists, ${ }^{7}$ the court nevertheless considered that these factors were not controlling in the situation before it.

For this twofold justification for the holding that the gift was contingent on survivorship, that is, the absence of words of present gift and the presence of the gift over, the opinion in Estate of Blake relies strongly on the earlier one in In re Rogers. ${ }^{\mathbf{8}}$ There, by dictum, the court seems to have accorded its approval to the much criticized distinction between a legacy given to a legatee and made payable to him at twenty-one, and a legacy merely given to a legatee at twenty-one. In the former instance the gift is said to be immediate, with postponement only as to the time of payment. Accordingly, no requirement of survivorship to that time is implied. In the latter instance, the time of payment is said to be annexed to the substance of the gift and survivorship to that time is a condition precedent. ${ }^{\circ}$ Such a distinction has been well characterized by able legal scholars as a "traditional, insubstantial" one ${ }^{10}$ and as seemingly "absurd." 11 On the basis of authority, however, it has been accorded the imprimatur of the $R e$ statement. 12

It would be erroneous to conclude from the Blake case that it is an established rule of California law that the absence of words of present gift results in an implied requirement that the beneficiary of the future interest shall survive to the time when such interest becomes possessory. Such a conclusion would be inconsistent with the supreme court's decisions in a prior and in a subsequent case. In Keating v. Smith, ${ }^{13}$ decided less than two years earlier, the decree of distribution had provided that on the termination of a trust (the duration of which was measured by the minority of the children) one-third of the corpus was "to go" to the testator's widow. The court held that this gave the widow a right which was not contingent upon her survivorship until the ternination of the trust. She had died prior to that time and during the minority of some of the children, but it was held that she nevertheless had an interest which passed to her heirs or devisees. The court said: ${ }^{14}$

TSee Restatenrent, Proferty $\$ \$ 258,259$ (1940) ; Fruchtman, Effect of a Gift of Intermediate Income upon Vesting of Legacies, 10 TeMrPLE L. Q. 41 (1935).

894 Cal. 526, 29 Pac. 962 (1892).

9 Clobberie's Case, 2 Vent. 342 (1677).

$10 \mathrm{McD}$ ougal, Future Interests Restated, 55 HARv. L. REv. 1077, 1095 (1942).

11 SREes, The LAw OF Future Interests $\$ 355$ (1936); for similar criticism, see 1 NossIran, Trust ADMmistration and Taxatron 321 (1945).

12 Restatentent, Property \$ 258, comment $e$ (1940).

13154 Cal. 186, 97 Pac. 300 (1908).

14 Id. at 191,97 P. $2 \mathrm{~d}$ at 302 . 
The question revolves itself, primarily, into one of construction. Did the terms of the decree of distribution establish in the widow a present interest, which could pass, upon her death, to her heirs or devisees? By the provisions of the clauses above quoted, one-third of the residue is, upon the termination of the minority of the children, to go to the widow. Her right to the possession of the principal of this third is postponed; but, under the -language of the decree, she is to receive it in any event. Except in regard to the time when it may come into her possession, there is no uncertainty. The gift is not made contingent upon the occurrence or nonoccurrence of any event whatever. There is no gift over in the event of her death, as there is in the case of the minor children. Furthermore, she is, during the existence of the trust, to receive one-third of the income of the property. That, at common law, this provision for the wife would have been regarded as creating in her a vested estate, and that, in the absence of statutory rule to the contrary, such estate, whether legal or equitable, would pass from her by inheritance or devise, are propositions that are not, and cannot be, questioned.

Several decades later in Estate of Wallace the supreme court reached a similar decision. ${ }^{15} \mathrm{~A}$ decree had distributed the residue of the estate in trust, to pay the testator's widow a specified sum per month out of the income and to pay the balance of the income to his two named daughters. The decree further provided that "upon the death or remarriage of the said widow, the said trust shall terminate and said trustee shall distribute the balance" of the trust property in equal proportions to the two daughters. One of the daughters predeceased the widow by several years. The court held that this daughter's share passed to her heirs as a vested remainder which did not lapse by reason of her death prior to the termination of the trust. The supreme court's opinion states that the question there presented "turns principally upon the meaning of the words 'shall distribute'."10 It then proceeds to distinguish "to distribute" from "to convey" and to conclude that unlike "to convey," the words "to distribute" have reference to the distribution or delivery of possession of property "to which the decedent's daughter already had a vested remainder."

Where do the Keating and Wallace cases leave Estate of Blake? Except for the second ground of the decision in the Blake case, i.e., the effect of the gift over in the event of death under thirty without leaving issue, what valid distinction can be made between the various wordings? "To go" and "shall distribute" are no more words of present gift when used with reference to the devolution of property on the termination of a trust than are the words "to demand and receive." The Blake case should not be considered as authority for any general principle that the absence of words of present gift of a future interest implies a condition precedent of survivorship. It can be explained and justified, if at all, ${ }^{1 \pi}$ simply as an application of the

1511 Cal. 2d 338, 79 P. 2d at 1094 (1938).

10 Id. at 340,79 P. $2 \mathrm{~d}$ at 1095 .

17 In view of the gift of the entire intermediate income prior to the beneficiary attaining thirty, there was a sufficient rebuttal of any implication of a requirement of survival arising from the wording being considered the equivalent of a gift "if" or "when" the beneficiary should attain the age of thirty. 
doctrine that "under crystallized rules of construction"18 a gift "to $X$ when he attains twenty-one" implies a condition precedent of survival to that age, ${ }^{10}$ al though a gift "to $X$, payable at twenty-one" does not. ${ }^{20}$

\section{Beneficiary Taking Title from Trustee}

The opinion in Estate of Wallace also suggests a question as to the effect in California today of a simple direction to the trustee "to convey" the corpus to the designated beneficiary on the termination of the trust. Both by virtue of the court's own language in the Waillace case and because of its very pointed reliance upon its earlier opinion in Estate of Dunphy, ${ }^{21}$ there is reason to infer that the court felt that use of the words "to convey" might have led to an opposite conclusion, that is, that survivorship was implied. A hint as to the basis for this differentiation lies in the court's statement that "shall distribute" refers to the delivery of possession of property, title to which had already vested. Clearly, such an interpretation could not be made of a direction to the trustee to convey. Nevertheless, this would seem unimportant. What reason is there for not concluding that the direction to convey the legal title to the beneficiary has no more bearing on the question whether his equitable title is vested or contingent than has the direction to deliver possession on the similar question as to whether the legal title is vested or contingent?

Though not specifically mentioned in its opinion, the court in the Wallace case may have had in mind another possible basis for differentiating between the effect of the words "distribute" and "convey", where the problem of the implication of a requirement of survival is involved. The argument has been advanced that in view of the provision of Civil Code Section 863 that "the beneficiary takes no estate or interest in the property,"22 his rights are necessarily contingent upon his personal survival until the time when he is entitled to receive the trust property. The validity of this contention seems to have been accepted for the purpose of argument by the supreme court in Keating $v$. Smith $h^{23}$ but the conclusion to which it led

18 Restatemient, Property \$ 257, comment $e$ (1940).

10 In the Keating and Wallace cases provision was made for the property to go to designated beneficiaries on the termination of the trusts. There was no suggestion that these ultimate beneficiaries must have attained any specified age. A gift to a person on attaining a particular age, however, necessarily suggests the possibility of a contingency not present in the first mentioned situation. If the wording be "if" or "on condition that" the specified age is attained, contingency is unquestionably connoted. Apart from authority, however, it is arguable whether a gift "at" the specified age or "when" the beneficiary attains that age should be placed in the same category. as those in which the words "if" or "on condition that" appear. The wording of CAL. Prob. CODE $\$ 28$ (see note 4 supra) also seems inconsistent with such a classification.

20 Restatenrent, Property $\$ 257$, comment $d$ (1940). A possible basis for distinguishing Estate of Blake from Estate of Keating and Estate of Wallace might conceivably be the fact that the Blake case was concerned with the construction of a will, while in the other two cases a decree of distribution was involved. Such a distinction, however, would be difficult to sustain either on principle or authority. It would be both lacking in substance and mischievous in application.

21147 Cal. 95, 81 Pac. 315 (1905).

22 "Except as hereinafter otherwise provided, every express trust in real property, valid as such in its creation, vests the whole estate in the trustees, subject only to the execution of the trust. The beneficiaries take no estate or interest in the property, but may enforce the perfornance of the trust." CaL. CIV. CoDE $\$ 863$.

23 Supra note 13. 
was avoided on other grounds. Under the terms of the will, the trustees had been there directed "to convey" the trust property to the respective beneficiaries on the termination of the trust on the youngest child's attainment of majority. The decree of distribution, however, after having distributed the property in trust, to terminate on the attainment of such majority, provided that the property was "then to go" to the named beneficiaries. The court pointed out that the will itself had attempted to create an invalid trust "to convey" within the rule of Estate of Fair"t but that by the decree the trustee's estate had been limited to the period of the children's minority, and that the words "to go" were "clear words of direct devise." The interest of the widow in the corpus, therefore, was not that of a beneficiary in a trust under Civil Code Section 863, but was a legal remainder not subject to any requirement of survival.

The same contention, accepted for the purpose of argument in the Keating case, seems to have been the principal basis for the district court of appeal's decision in Estate of Hamon. ${ }^{25}$ In that case, one-seventh of the residue of the property had been left in trust for one of the testatrix's daughters. The decree of distribution, following the language of the will, provided for payment of the income to the daughter until the expiration of 20 years or the death of the daughter's husband, whichever event should first occur. At that time, it provided, the trustee "shall deliver" the property to the daughter. She died prior to the expiration of the twenty years and her husband as executor of her estate claimed the trust property. The court held, however, that the daughter's interest in the property was contingent on her survival. Civil Code Section 863, but not the Keating case, was relied upon in support of this conclusion.

The Keating and Hamon cases are the principal ones ${ }^{26}$ in which the contention has been made that Civil Code Section 863 imports the requirement of survival on the part of the beneficiary of trust property. It seems clear that the actual decision in the Hamon case, if based simply upon the wording that the trustee "shall deliver," 27 is inconsistent with the decisions of the supreme court in both the Keating and Wallace cases, where the

24132 Cal. 523, 60 Pac. 442, 64 Pac. 1000, 84 Am. St. Rep. 70 (1901). In 1929 the rule was changed by the repeal of CAL. CIv. CODE $\$ \$ 847$ and 857 , on which the decision in Estate of Fair was based.

25136 Cal. App. 517, 29 P. 2 d 326 (1934).

26 See also Anglo California Nat. Bank v. Kidd, 58 Cal. App. 2d 651, 137 P. 2 d 460 (1943). There the court cited, inter alia, the Hamon case and Car. Crv. CODE $\$ 863$, for the proposition that the beneficiary has no title or interest in the trust property. It apparently, however, did not rely chiefly upon this point to support its conclusion that survival was required. The controlling factor was the language of the will generally, and particularly the gift over in the event of the beneficiary's death prior to the termination of the trust without leaving issue.

27 A possible justification for implying the requirement of the beneficiary's survival until the termination of the trust may have been an implication of hostility on the part of the testatrix toward the husband of the beneficiary. According to the provisions of the will the beneficiary (the daughter of testatrix) was not to have the corpus of the trust property until the expiration of twenty years or the death of the daughter's husband, whichever event should occur first. Such a provision, however, may have been motivated by considerations other than hostility toward the daughter's husband and it is arguable whether an inference of such hostility would have been warranted. 
wording was "to go" and "shall distribute" respectively. The reference to possession rather than to the passage of title implicit in the use of the word "deliver" in the Hamon case is equally as strong as that implied from "go" or "distribute" in the two supreme court decisions.

The rule of the Hamon case, however, is not a valid one even in a situation where the will or decree of distribution directs the trustee "to convey" to the beneficiary. ${ }^{23}$ It certainly seems undesirable to make any important legal consequence turn on the chance use of a particular word instead of any one of several substantial equivalents. Furthermore, there is nothing in the trust concept as stated in Section 863 of the Civil Code which justifies the conclusion that the requirement of survival of the beneficiary is implied from the trust device. Any contention that this section means that the beneficiary has no equitable title but merely a personal right against the trustee has been definitely set at rest by two later cases. In these decisions, one by the supreme court ${ }^{20}$ and the other by the district court of appeal, ${ }^{30}$ Section 863 was construed as referring to the legal title only, and as recognizing that the beneficiary has an equitable title to the trust property.

\section{Effect of Gift Over}

In its reliance upon the gift over in the event that a beneficiary should die under thirty without leaving issue as itself implying a condition precedent of survival until thirty, Estate of Blake $e^{31}$ is opposed by the great weight of authority both in this country and England. ${ }^{32}$ As well stated by a distinguished legal scholar and writer in this field, "the effect of the gift over on vesting is, it is believed, purely a matter of rational inference." 33 By way of example, Mr. Kales further points out how in certain situations the gift over can furnish no argument either that the original gift is vested or that it is contingent. In other cases, however, it may have a legitimate implication in rebuttal of a prima facie conclusion as to either a vested or a contingent character. Mr. Kales mentions a situation practically identical

28 In Estate of Welch, 83 Cal. App. 2d 391, 188 P.2d 797 (1948), the only words of gift in the will were in the direction to the trustee to convey the property to the beneficiary on the latter's attaining 25 . The court held that there was no requirement of the beneficiary's survival and that on his death prior to attaining that age the right to the trust property passed to his heirs.

See, also, Estate of Newman, 68 Cal. App. 420, 229 Pac. 898 (1924). Decree of distribution provided that on termination of trust, trustee should "convey, deliver, pay and transfer to any heirs at law ... all of said trust estate." This was held to create an interest which vested in those who were the heirs of the testator at the time of his death.

NosSMran, op. cit. supra note 11, at 315-16, beheves that by implication the Wallace case overrules Estate of Hamon and that the particular form of expression used with reference to the transfer from trustee to beneficiary should be immaterial as far as the problem of vesting is concerned.

20 Title Ins. \& Trust Co, v. Duffill, 191 Cal. 629, 218 Pac. 14 (1923); Note, 13 Carrr. I. Rev. 76 (1924).

30 Lynch v. Cunningham, 131 Cal. App. 164, 21 P. 2d 154, 21 P. 2d 973 (1933).

31 Supra note 5 .

32 Restateminnt, Property \$254 (1940); Simes, The Law of Future Interests \$77; Jararan ON WIIIS 1393 (7th ed. 1930).

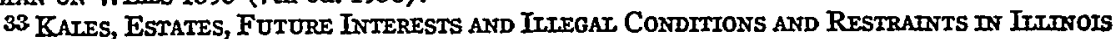
600 (2d ed. 1920). 
with that presented by the Blake case; a gift to $A$ at twenty-one which, standing alone, is assumed to be contingent, that is, subject to the requirement of survival. "If however" he continues, "the gift over is upon the death of $A$ under twenty-one and without issue, it may well be argued, that an intent is shown that $A$ is to be deprived only if he died under twenty-one without issue. This intent could not possibly be effective unless the preceding interest were vested." 34

The opinion in the Blake case, ${ }^{35}$ it should be noted, makes a diametrically opposite deduction. Not satisfied with the conclusion that the gift over has no logical bearing either way on the problem of vesting, the court there asserts that the gift over affords affirmative evidence of the contingent character of the original gift. ${ }^{36}$ Such a holding seems to have been necessary, if the court's ultimate decision was to be supported. According merely a negative effect to the gift over would probably have resulted in a holding that the original gift was vested. As the court recognized in its opinion, the fact that the beneficiary was to receive the entire income from her share in the corpus was evidence of the vested character of the gift. The authorities are alniost unanimous in support of the view that such gift of the income overcomes the prima facie contingent character of the gift of the corpus at the specified age and nrakes the entire gift vested. ${ }^{37}$

In certain later cases in which the district courts of appeal have properly concluded that the gifts in question were vested and subject to no implied requirement of survival, Estate of $B l a k e^{38}$ has been distinguished because of the absence of any gift over in the case at hand. ${ }^{39}$ Unfortunately, however, where there has been a gift over, Estate of Blake has been a compelling precedent in several instances for implying the requirement of survival.40

${ }^{34}$ Kales, op. cit. supra note 33 , at 601 .

35 Supra note 5.

36 The only authority cited in support of this conclusion was In re Rogers, supra note 8. It is not clear that on the facts presented in that case it was necessary for the court to have made any decision on the question whether the grandson's survival to the specified age was a condition precedent. The express gift over in the event of his failure to attain such age could have been construed as being applicable in any situation, so as to have precluded his successors in interest froin claiming the legacy.

37 See authorities cited note 7 supra. See also Turrentine, Suggestions for Revisions of the California Civil Code Regarding Future Interests, 21 CALIF. L. REv. 1, 4, n. 19 (1932) for criticism of the Blake case.

38 Supra note 5.

39 Estate of Riemer, 69 Cal. App. 2d 634, 159 P.2d 677 (1945). Will left three houses "to my grandson ... when he becomes 21 years of age, in the meanwhile his mother ... to be his guardian"; devise lield vested, even as to income before 21.

Estate of Klein, 23 Cal. App. 2d 708, 74 P.2d 79 (1937). Will gave residue to two daughters in trust, to continue as to one daugliter's sliare until she attained 25 , as much of income and principal necessary for lier support to be paid to her in meantime, and when she attained 25 balance of income and principal to be paid over to her by trustee; daughter's interest held to have vested at death of testatrix and to have passed to her executor on her death under 25 .

Estate of Welch, supra note 28 (for facts see note 62 infra).

See, also, Estate of Backesto, 71 Cal. App. 409, 235 Pac. 670 (1925), in which Estate of Blake and Estate of Rogers, along with Estate of Winter, 114 Cal. 186, 45 Pac. 1063 (1896), were distinguished as construing wills "which made dispositions contingent upon the survival of the beneficiary at the date possession was to be transferred."

${ }^{40}$ San Diego Bank v. Heustis, 121 Cal. App. 675, 10 P. 2d 158 (1932). Testanentary trust to pay portion of income to testator's son for 10 years and at the end of that time the trust 


\section{Class Gifts}

In all of the instances previously considered, the gifts have been to specifically named individuals. It is with respect to such beneficiaries that the question whether there is implied condition precedent of survival has been raised. The same problem arises when the gift is to a class-a situation which usually occurs without any specific designation or naming of the particular members or individuals. At first glance the argument for implying a condition precedent of survival seems somewhat stronger here than when the gift is simply to one or more individuals. After further reflection, however, the validity of any rational distinction in this respect appears difficult to sustain. If property is left to $A$ for life, remainder to $B$ and $C$ in equal shares, there is no requirement that $B$ or $C$ shall survive the life tenant, $A$. What convincing reason can be given for a contrary result where, on $A$ 's death, the remainder is to go, not to $B$ and $C$, but "to the children of $D$. . It may be contended that a reason exists because of the difference which would result under the two wordings in case one of the prospective beneficiaries should predecease the testator. Where the remainder is given to $B$ and $C$ and $B$ predeceases the testator, unless there is an applicable anti-lapse statute, the gift of one-half of the remainder ordinarily will fail. The other named beneficiary, $C$, will take merely his original one-half. On

estate to go to and be conveyed and delivered to said son, with gift over if son should die during the 10 years; beneficiary's interest held to be contingent, not vested.

Anglo-California Nat. Bank v. Kidd, supra note 26 . Testamentary trust to pay income to a son of testator until he attained thirty, when the trustee should pay and deliver the principal to him, with a gift over on his death under thirty without leaving issue; attainment of age held to be condition precedent.

Estate of Faris, 89 Cal. App. 2d 515, 201 P. 2d 63 (1949). Appeal from a decree of distribution which interpreted a will as creating a trust and, accordingly, distributed the property to a trustee. The will gave all the testator's property to his son, "to be turned over to him at the time he becomes (25) twenty-five years of age." Until that time the will provided that the estate was to be handled by the executors, who should pay the son as inuch per inonth as they deemed advisable. In the event that the son should die leaving no children, the property was given to the testator's three brothers. The only contention on the appeal, which was by the son, was that no trust was created. It was held, and it would seem properly so, that the intention to create a trust was sufficiently apparent on the face of the will. In its opinion, however, the court went on to say that the will "does not purport to make an immediate gift" and that an intention clearly appears "that the property should not vest in the son unless and until he reached the age of 25." Such a holding seems as questionable as the similar one in Estate of Blake, on which the court here relied. As far as the gift of the income was concerned, the situation here was less favorable to the beneficiary than in the Blake case, where the entire income was given without qualification. Unlike the Blake case, however, there were here words of present gift: "I leave all my estate ... to my beloved Son ... to be turned over to him at ... twenty-five."

See, also, Estate of Easterday, 45 Cal. App. 2d 598, 114 P.2d 669 (1941). Here, the decree of distribution, following the language of the will, provided for the termination of a trust on the death of the life beneficiary, the testator's son. At that time, one-fourth of the residue of the property was to be delivered to two of the testator's nephews and a mece. This was followed by a provision, again in the language of the will, that in the event of the deatl of either of the nephews or of the niece without issue such share should go to the survivor or survivors. The court poimted out that the correctness of the decree as to the proper interpretation of the will in this regard was not an issue on the present appeal. It did, lowever, state that the decree as rendered contained a gift by implication in the event of the death of any one of the named legatees with issue during the period prior to termination of the trust on appellant's death. This gift by inplication the court said was in favor of such issue living at the termination of the trust (citing Estate of Blake). 
the other hand, if the wording had been that the remainder should go "to the children of $D$," upon the one child, $B$, predeceasing the testator, the surviving child, $C$, would take the entire interest. ${ }^{41}$ In both of these instances, however, the requirement of survival exists. The only difference is that when the remainder is given to the class, the surviving member takes not only his own share but also the share of the other who fails to survive. An essential dissimilarity is readily discernible between the situation where a class member predeceases the testator and where a member who has survived dies before his interest becomes possessory. In case of the death of a class member before the testator, the latter's intention to limit the membership of the class to those who survive him is implied because otherwise there would be a partial failure of the gift. No such justification exists where a class member survives the testator but fails to survive to the time when the future interest becomes possessory. The alternatives are not partial failure of the gift, on the one hand, and a taking by the surviving inember of the class, on the other. The choice is between the surviving class members and the successors in interest of the beneficiaries who failed to survive. In no event will there be any partial failure of the gift.

In Estate of Cavarly, ${ }^{42}$ however, the supreme court apparently found that an implied condition precedent of survivorship existed because of the circumstance that the gift of the future interest was to a class. The question arose in connection with the problem whether the will violated the provisions of Civil Code Section 715 and related sections regardmg restraints against the absolute power of alienation. The will provided for the termination of a trust when the youngest of the testator's children reached thirty, or would have reached that age had he lived. At that time the trustee was directed "to divide and distribute the property in equal shares among such of iny children as may then be living and the issue of any deceased child ... per stirpes." The court held that "issue who might have taken under the trust, but who did not survive until the appointed time for distribution" would not be qualified to take. Two independent reasons were relied upon in support of this conclusion. First, the court asserted that it was "a rule of construction of a gift to a class that only those are included who are in existence at the time of the distribution. (Gray on Perpetuities, sec. 698.)" 43 The citation of this particular section of Gray is clearly erroneous. Section 698 consists of a single short sentence dealing with one of the periods of accumulation permitted by the Thellusson Act. An examination of various other sections of Gray (1st ed.) bearing somewhat similar numbers, however, indicates that sec. 638 is probably the one to which the court intended to refer. It contains the following sentence, which is very similar to the one above quoted from the court's opinion in the Cavarly case: "The general rule of construction is that, upon a gift to a class, only those are

41 Atkinson on Wrils 728 (1937); 3 Page on Wills $\$ 1060$ (1941); THFfany on ReaI Property § 1082 (3d ed. 1939); Restatement, Property, INTroductory Note c. 22 (1940). It is assumed that there is no applicable anti-lapse statute.

42119 Cal. 406, 51 Pac. 629 (1897).

43 Estate of Cavarly, supra note 42 at 410,51 Pac. at 630. 
included who are in existence at the time of distribution; and the time of distribution is considered to be when the first of the class is entitled to his share." Gray was making this statement in the course of a discussion of the famous case of Kevern v. Williams ${ }^{44}$ and in considering the problem there raised as to when the class closed, so that after born members would not be allowed to qualify. The possibility of a requirement that previously born members should survive to the time of first distribution was not under consideration. In fact, as Gray indicates in the succeeding sentences of the same section, there is no such implied requirement of survival. Except for the one sentence, and only when it is taken out of its context, Section 638 of Gray is direct authority against the court's conclusion in the Cavarly case. ${ }^{45}$ The rule generally followed both in this country and England is also contra. ${ }^{48}$

The court's second reason for concluding that issue who did not survive until the time for distribution were not qualified to take was the language of the will. The provision there was for distribution "among such of my children as may then be living and the issue of any deceased child ... per stirpes." 46 The court very evidently felt that the express requirement of the children's survival applied by implication to the alternative gift to the issue. In such a situation, there is more of a conflict of authority as to whether a requirement of survival is implied than where there has been no reference to survival as a requisite under any circumstances. ${ }^{47}$ In the former situation, the testator has certainly been somewhat aware of the possibility of nonsurvival. Nevertheless, as far as his express language goes, he has required survival by the first mentioned beneficiaries but not by those named in the alternative. The maxim "the expression of the one is the inclusion of the other" may well be apphicable. This argument seems additionally weighty in the light of the basic presumption or rule of construction in favor of early vesting. On the other hand, what reason is there to believe that a testator desired to impose survival by the children as a condition precedent to their taking but to dispense with any such requirement as to their issue? The instances would seem to be rare indeed where such a distinction would be actually intended.

The view expressed in the Cavarly case that a requirement of survivorship is implied from the fact that the gift of the future imterest is to a class is not ouly out of line with the prevailing view but is contrary to Civil Code Section 1337 (now the first portion of Probate Code Section 123) which read as follows:

145 Sim. 171, 58 Eng. Rep. 301 (1832). See Leach, Perpetuities in a Nutshell, 51 Harv. L. REv. 638,658, n. 57,659 , n. 62 (1938).

45. It may be worthy of note, that in the latest edition of Gray, The RULE AgarNsr PrRPETUITIES (1942), this particular sentence is eliminated.

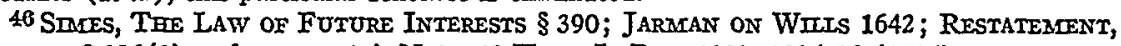
Property \& 296(2) and comment $j$; Note, 48 Harv. L. REv. 1202, 1225-26 (1935).

40a Estate of Cavarly, supra note 42 at 408, 51 Pac. at 629. (Emphasis added.)

47 SIMIES, THE LAW OF FUTURE INTERESTS § 395. The English rule and the one recognized by the Restatement, however, are the same as in the situation where there is no express requirement of survival even as to the children, i.e. no requirement that the issue must survive is implied. Jarsan on Witis 1304; Restatentent, Property \$250, comment $k$ and illustration 4, and $\S 254$, comment $d(1940)$. 
A testamentary disposition to a class includes every person answering the description at the testator's death; but when the possession is postponed to a future period, it includes also all persons coming within the description before the time to which possession is postponed.

In the opinion in Estate of Cavarly ${ }^{48}$ the court specifically mentions the provision of the latter part of Section 1337, which states that persons coming within the description before the time to which possession is postponed are to be included in the class. It apparently ignored the provision of the first portion of the section, that the class includes every person answering the description at the testator's death. By strong implication, this negatives any requirement of survival to the time to which possession is postponed. ${ }^{40}$ Instead of applying this provision, the court, as previously pointed out, misconstrued a statement in Gray on Perpetuities to mean that survival is impliedly required in a class gift.

The correct interpretation and application of Civil Code Section 1337 (now part of Probate Code Section 123) was made by the district court of appeal in Estate of Backesto, ${ }^{51}$ decided many years after the Cavarly case and without mention of it. The will in the Backesto case had left the entire estate to the testator's wife and directed that after her death it should be sold and the proceeds divided among the children of specified brothers and sisters of the testator and his wife. One of these brothers had a daughter who died in the lifetime of the testator's wife. A daughter of this deceased daughter claimed her mother's share but was excluded from participation by the trial court. On appeal this decision was reversed and the daughter's daughter awarded the share which her mother would have received had she not predeceased the life tenant. In a clear and succinct opinion by Justice Nourse, the district court of appeal pointed out that appellant rested her case on the provisions of Sections 1337 and 1341 of the Civil Code. Referring to these sections (and also to Sections 1342 and 1343) the court said: ${ }^{62}$

All these sections show the unmistakable intention of the statutory law to declare that a devise or bequest shall vest at the testator's death unless some other intention is expressed in the will. This policy has been recognized and approved by the California decisions .... It has thus become a fixed policy in the interpretation of clauses of this nature found in a will that a disposition to a class includes every person answering the description at the testator's death, and that the estate vests in them as they come in esse though the possession is postponed to a future period.

48 Supra note 42 at 410,51 Pac. at 630.

49 In the code commissioners' notes to $\$ 1337$ (now the first portion of Car. Prob. Code $\S 123$ ) in the 1872 annotated edition of the Civil Code, the first case cited is Tucker v. Bishop, 16 N.Y. 402 (1857). In that case, at 404, referring to a class gift to children where membership of the class was suhject to increase by future births prior to distribution, the court said, "and on the death of any of the children previous to the period for distribution, their shares will go to their respective representatives." Among other cases cited by the New York court in support of this conclusion was Middleton v. Messenger, 5 Ves. 137 (1799). The latter is the leading early English case supporting the rule that class memhers are not required to suryive to the time of distribution in the absence of a contrary intent. See authorities cited in note 46 supra.

51 Supra note 39.

62 Id. at 416, 235 Pac. at 672. 
The holding in Estate of Backesto has additional weight because of the denial by the supreme court of a hearing in that case..$^{53}$ The correct rule was also applied in a more recent decision of the district court of appeal. ${ }^{54}$ Justice Peters there pointed out that the fact that the remainder was to a class and subject to open and let in after-born members in no way assisted the argument that such a remainder was contingent.

\section{Implications from Word "Vest"}

Occasionally a will or decree of distribution provides that the property shall "vest" in the beneficiary at some future date. From the use of this particular word there arises a new phase of the problem as to whether a requirement of survival exists. The word "vest" unquestionably merits the Hohfeldian epithet "chameleon-hued," a characterization which that learned legal writer and scholar evidently reserved for juristic terms of "convenient and seductive obscurity." Examples can be given of at least five different meanings, from the legal viewpoint, embodied in the words vest or vested. ${ }^{56}$ In the first place there is the highly technical (sometimes termed, "feudal") meaning, particularly applicable to remainders which are subject to no condition precedent. Secondly, vested may connote indefeasibly vested, applymg to an interest which is not only vested in the first sense but also is not subject to any divesting condition subsequent. In the third place, vest may refer to the vesting in possession or enjoyment rather than in interest or right. Fourth, vested may be used to designate a transmissible interest, that is, one which is not subject to any condition of survival, whether or not it is subject to any other condition precedent. Fifth, vested may refer to a right or interest claimed to be entitled to some particular protection under doctrines of constitutional law.

Is a condition precedent of survivorship implied from a provision that a property interest shall vest at a future date? The opinion of the majority of the supreme court in Estate of Easter ${ }^{57}$ supports an affirmative answer to the question. The decree of distribution (differing from the language of the will ${ }^{\text {ss }}$ ) had provided that on the termination of a trust on the widow's death, "all of the property ... shall go to and vest in the heirs at law ...." After the widow's death, shares in the corpus were claimed by the respective successors in interest of the widow and of a son of the testator who had survived hin but.had predeceased the widow. Reversing a decision of the

63 Id. at $416-417,235$ Pac. at 672.

54 Estate of Norris, 78 Cal. App. 2d 152, 177 P.2d 299 (1947), rehearing denied, April 17, 1947. See Note, 36 CAIIF. I. REV. 129 (1948) on the additional problems presented in the case. 5527 YALE L. J. 66, 92 (1917). "License" was the term there characterized by Professor Hohfeld as "chameleon-hued."

56 Jartan on Wints 1325-1330; Leach, Cases on Future INTERests 255-256 (2d ed. 1935); Smans, The Law of Future INTEREsts § 347. (As to the fifth meaning) Spreckles v. Spreckels, 116 Cal. 339, 48 Pac. 228 (1897) ; Gray, The Rule Agatnst Perpetuities § 118, n. 3 ; CoOLEY, Constitutional IIMTITATIONS 745 (8th ed. 1927).

5724 Cal. 2d 191, 148 Pac.2d 601 (1944); see, also, Comment, by the present writer, 32 Caltr. I. Rev. 320 (1944).

58 It is well established in California that in case of confilict between the provision of the will and the decree of distribution, the latter controls. Estate of Loring, $29 \mathrm{Cal}$. 2d 423, 175 P.2d 524 (1946); Note, 29 CaIrF. L. Rev. 438 (1941). 
district court of appeal, ${ }^{59}$ which had permitted these successors to share, the supreme court held that the widow and son were to be excluded from the group of "heirs" because of the provision in the decree that the interest of the heirs should vest at the time of the termination of the trust. This is a result opposed both to the primary meaning of the term "heirs," as designating the persons who would be entitled to the property on the death of the ancestor according to the code provisions on imtestate succession, and to the basic presumption or rule of construction in favor of vesting. An interpretation in accordance with both of these principles, as urged in Justice Traynor's admirable dissenting opinion in the supreme court and by the majority in the district court of appeal, might well have been made. There is ample authority for construing the word vest as referring not to the vestmg im interest but rather to the vesting in possession. ${ }^{60}$ Such an interpretation would also have made unnecessary the unconvincing assumption in the majority opinion that the wording of the decree of distribution, which differed from that of the will, imported a conclusive prior adjudication of the question whether the will imposed the requirement of survival. It would also have been firmly supported by a previous supreme court decision ${ }^{\text {O1 }}$ interpreting a provision in a will that the property "shall not so vest in such children until the death of both my said brothers" as referring to vesting in possession rather than interest. A recent well reasoned decision of the district court of appeal has made a similar interpretation of a provision in a will that the beneficiary of a trust should have no vested right to the property before attaining a specified age. ${ }^{62}$

5959 A.C.A. 951, 140 P. $2 d 186$ (1943).

60 See authorities cited note 56 supra.

61 Estate of Glann, 177 Cal. 347, 170 Pac. 833 (1918).

62 Estate of Welch, supra note 28. The will left one-half of the testator's real property in trust, both income and principal to be used in discretion of trustees for maintenance and education of a grandson until he attained 25; upon his attaining that age, the trustee was to convey to him the balance of the income and principal of the trust estate. The will further provided that the grandson should have no vested right in the income or principal until he attained 25, except to the extent that in the discretion of the trustee the trust estate should be used for his maintenance and education. The grandson survived the testator but died under 25 as the result of a plane crash in Belgium while serving in the Army Air Forces. He left a wife and child who claimed the trust estate. The emotional pull of this factual situation was of course strongly against the recognition of any implied condition of survival by the original beneficiary. The trial court nevertheless lield that such a condition was implied and that the testator's daughter, the residuary devisee and legatee in the will, was entitled to the property. This decision was reversed on appeal. The presumption in favor of a devise vesting at the death of the testator was applied, in spite of the provision in the will that the grandson should have no vested right until be attained 25. The latter provision was interpreted to refer to vesting in possession rather than in the technical or restricted sense of the tern.

But cf. Estate of Wattson, 66 Cal. App. 2d 743, 153 P. 2 d 87 (1944). Here, the will provided that the principal and undistributed income of the trust estate should "go to and vest in" the beneficiary when he attained 35 . He died under 35 and apparently it was clear to the court that "vest" was used in its techmical restricted sense and not simply as referring to possession.

Also, cf. In re De Vries, $17 \mathrm{Cal}$. App. 184, 119 Pac. 109 (1911). The will read that upon the termination of a life estate in the same property already given by the will the testator gave and devised this property to his son. It further provided that if the son should predecease his (the son's) wife and slould leave no issue surviving and should his death occur before the property given to him "vests in him," the property should go to the wife. In accordance with the presumption in favor of vesting (and, it would seem, very properly), the son's remainder was held to lrave vested at the testator's death. In addition to this, the provision in favor of the son's 


\section{The "Blood of the Testator" Canon}

A recognized rule of construction to which resort is sometimes had for the purpose of resolving uncertainties in wills is that when two conflicting interpretations are possible, the one is to be preferred that will result in the property going to those of the blood of the testator rather than to strangers. ${ }^{63}$ This rule seems occasionally to be relied on to justify or strengthen the contention that there is a requirement of survival by the beneficiary of a future interest. ${ }^{64}$ This canon of construction may very properly be applied in situations not involving the question of the existence of an implied requirement of survival. ${ }^{65}$ It also is possible that it may sometimes be a relevant factor even in connection with the survival question. Care should be exercised, however, that this canon not be permitted to undermine the more fundamental one in favor of early vesting. In almost every situation involving the gift of a future interest to a blood relative, an added requirement of survival would necessarily result in postponing the time when the property might come into the hands of strangers to the blood of the testator. If the beneficiary who has an indefeasibly vested interest dies before his interest becomes possessory, there is always a very considerable possibility of his interest then passing to a surviving spouse or to a stranger, neither of whom would be of the blood of the testator. To imply a requirement of survival would, of course, prevent this. But to sanction such an implication would leave little remaiming of the constructional preference in favor of

wife was held to apply only if the son died before the testator. In other words, "vests" was given its technical meaning. The principal, and perhaps the only, controversy in the case was as to whether the remainder was vested or contingent. Even though it was vested, however, the provision for the remainderman's wife in the event of his death without issue before the remainder "vests in him" might be interpreted as referring to vesting in possession. In that case there would have been a gift over in favor of his wife, in case he died without issue during the continuance of the hife estate. As construed by the court, the gift to the wife was merely substitutionary, i.e., it applied only if the remainderman predeceased the testator and left no issue. The result, of course, is in accordance with the constructional preference in favor of early vesting and indefeasibility. It seems probable, however, that the testator's intention was to have the remainder defeasible during the continuance of the hife estate. (Cf. ResTateNIENr, ProperTy $\$ 251$ (1940); CAI. PROB. CODE $\$ 122$ : "Words in a will referring to death or survivorship, simply, relate to the time of the testator's death, unless possession is actually postponed, when they must be referred to the time of possession." Estate of Winter, supra note 39 at 186, 45 Pac. at 1063.) It is quite possible that it was the influence of Estate of Blake and the fear that a gift over interpretation would be inconsistent with the construction in favor of vesting in its primary sense that prevented the interpretation here suggested.

63 Estate of Lawrence, 17 Cal. 2d 1, 12, 108 P. 2d 893, 899 (1941) (rule held inapplicable "where in order to prefer those of the blood of the testator it is necessary to ignore the presumption against intestacy and in favor of upholding the intent of the testator as expressed in his will") ; 2 PoweiL, REAL Property 682 (1950).

64 Estate of Hartson, 218 Cal. 536, 24 P. 2d 171 (1933); Estate of Clark, 64 Cal. App. $2 d$ 636, 149 P.2d 465 (1944).

65 Estate of Boyd, 24 Cal. App. 2d 287, 74 P. $2 d 1049$ (1938) (will interpreted to give intermediate life estate to certain blood relatives before remainder to charitable corporation); Estate of Wilson, 65 Cal. App. 680, 225 Pac. 283 (1924) ("heirs" of testator in a testamentary gift of a contingent remainder interpreted according to succession statutes in force at date of execution of will rather than at date of death, so as to prevent property going to relatives of predeceased husband of testatrix under CAL. CTv. Code § 1386, now CAI. Prob. Code § 229); Wood v. Mitcham, 92 N.Y. 375379 (1883) (gift over on death of a grandchild of testator to grandchild's brothers and sisters held restricted to brothers and sisters of the full blood, so as to exclude half brothers and sisters not related to the testator). 
early vesting and early indefeasibility. ${ }^{66}$ It would be tantamount to implying a condition precedent of survival wherever a blood relative was the beneficiary of the gift of the future interest. It would not seem improper, however, to permit the "blood of the testator" canon of construction to lend additional weight to other factors which tend to support the conclusion that survivorship by the beneficiary is required by the particular will. ${ }^{67}$

In resorting to the "blood of the testator" canon of construction in an endeavor to solve the problem whether there is an implied requirement of survival by the beneficiary of a future interest, care should also be exercised not to place undue emphasis on the fact that because of events which have taken place after the death of the testator, failure to imply such a requirement would necessarily result in those not of the blood of the testator taking the property. Very frequently the question of construction involving the requirement of survival is not raised until the future interest has become possessory. At the time the will took effect, what was simply the possibility, under the one construction, of the property later passing to strangers to the testator's blood, may, by the course of events have become an actuality. That fact, however, should have no greater bearing on the problem as to the choice between the two conflicting interpretations than existed in the beginning. The actual course of events is no more relevant in this situation than in one where the question is whether the rule against perpetuities has been violated. ${ }^{\text {es }}$

An example of failure, in dealing with the "blood of the testator" canon, to note the distinction between the situation existing at the time the will takes effect and the one which has developed as the result of subsequent events, is furmished by the supreme court's opinion in Estate of Hartson. ${ }^{69}$ In that case, a decree of distribution had set up a testamentary trust that was to continue until the death of the survivor of the testator's children. It provided for monthly payments of one-third of the income to each of the three named children. It further provided that on the death of any child, his share of the income should be paid monthly to his legal heirs, "if there should be any living at such tine." One of the children, a son, died leaving a wife and daughter surviving him. The wife subsequently predeceased the daughter. Sisters of the wife, as her residuary legatees, claimed her share of the income. The court held, however, that after the wife's death the daughter was entitled to all the inconie. It was apparently of the opinion

66 See Restatement, Property § 243, comment $j$ (1940) for recognition that the "blood of the testator" canon should not overcome this constructional preference in favor of early vesting and indefeasibility.

67 An example of such a situation is furnished in Estate of Norris, stipra note 54. The "blood of the testator" canon was rehed on to support the implication of the requirement of survival resulting from the use of the alternative phrase "or their legal heirs." The court decided, however, that any such implication that survival was required was rebutted by other provisions of the decree of distribution.

68 As to the perpetuity situation, see Gray, The Rute Agatnst Perpetuities 208 n. 1 ; Leach, supra note 44, at 642-3; REstatenent, Property \$ 370, comment $k$ (1944).

69 Estate of Hartson, supra note 64 . See also Estate of Clark, supra note 64 . The California courts are not alone in overlooking the impropriety of applying the "blood of the testator" canon of construction in the light of events which transpire long after the will takes effect. See, e.g., Loving's Estate, 159 Pa. Super. 339, 48 A. 2d 39 (1946). 
that the phrase "at such time" did not clearly refer to the time of the son's death but might also refer to the time of each monthly payment; that since there was a postponement of possession to the date of each payment, the rule laid down by Probate Code Section $122^{70}$ should govern; that is, "living at such time" should be interpreted as referring to the time of each payment. Any particular monthly income payment, therefore, should be made to those only of the heirs of the deceased child who were living at the time of such payment. This conclusion was strengthened, the court reasoned $^{71}$ (1) by the "blood of the testator" canon, and (2) by the express provision for distribution of the corpus on the termination of the trust to the surviving heirs of each child. The court's conclusion that the language of the decree of distribution should be interpreted as requiring survival by each heir to the time of the particular monthly income payment seems entirely justifiable independently of the "blood of the testator" canon. It is submitted, however, that in the light of the particular facts involved, this canon of construction was not a relevant factor. The will or decree of distribution should be interpreted as of the date when it took effect, in the light of various possible alternatives as to future events, and should not be affected in any way by reason of the particular alternative which actually happened. When the will or decree took effect, it could not be known whether the son's heirs would include a person not of the blood of the testator, or even if they should, whether an heir who was of his blood would survive an heir who was not.

\section{Conclusion}

In general, the decisions of both the Califorma Supreme Court and the California District Courts of Appeal of the last two decades adequately recognize and apply the rule of preference for early vesting and early indefeasibility. Accordingly, they ordinarily refuse to find any implied requirement of survival on the part of the beneficiary of a future interest. An obstacle, however, in the way of conformity with this position seems to be the forty-year-old decision in Estate of Blake. Its emphasis on the absence of words of present gift is out of line with other supreme court decisions. Its conclusion that survival is implied because of a gift over finds little support elsewhere. It unduly minimizes both the effect of a gift of the intermediate income and the weight of the recognized constructional preference in favor of early vesting. The principle of stare decisis is not a sufficient reason why Estate of Blake should not be definitely overruled. It is obvious, however, that no judicial interpretation can ever eliminate the necessity for careful draftsmanship in the preparation of instruments providing for the future interests. To preclude the possibility of any question subsequently arising as to an implied requirement of survival by any bene-

70 "Words in a will referring to death or survivorship, simply, relate to the time of the testator's death, unless possession is actually postponed, when they must be referred to the time of possession."

TI Estate of Hartson, supra note 64 at 540-1, 24 P.2d at 173. 
ficiary it would frequently seem desirable to embody in the will or decree of distribution a provision worded substantially as follows:

In the event that any beneficiary [who has survived the testator] shall die before the time specified herein for receiving payment or possession and no other disposition of the property has been expressly provided for, the lawful successor or successors of such beneficiary shall be entitled to the property in the same manner and to the same extent as the original beneficiary would have been had he survived to that time. 